\title{
Attitudes towards Research among Bachelor of Pharmacy and Doctor of Pharmacy Students: A Study from Tertiary Medical Institute
}

\author{
Dr. Sai kiran Pasupula ${ }^{1}$, Dr. L. C. Obulesu ${ }^{2}$, Ammajan $^{3}$, Dr. K. Bhaskar Reddy ${ }^{4}$
}

\section{ABSTRACT}

Background: Research plays a key role in day to day life and research became a part of study curriculum. Attitude towards research plays a key role in knowledge among medical as well as Para medical students. Aim: To assess the attitude towards research among pharmacy internees. Methodology: This study was carried out at department of psychiatry, RVS medical college \& hospital..Study sample includes the pharmaceutical students (Bachelor of Pharmacy and Doctor of Pharmacy) doing their internship at Sri venakteswara college of pharmacy are included in the study. Attitudes towards the research was measured using Attitude towards research scale (ATR Scale). Conclusion: Attitude towards the research among pharmacy internees is variable which indicates the need to increase awareness of research among their graduate period.

Keywords: Research, Attitude, Pharmacy internees.

Research plays a prominent role in day to day life and research is one of the most important intellectual possessions for every human being to change his way life in accordance to the needs and demands of the society. Research is a key ingredient in shaping up the world that man lives in and the new experiences they see and encounter in their surroundings. ${ }^{[1]}$ Students at the undergraduate level usually tend to view research methods courses negatively ${ }^{[2]}$. Many records could show evidences of the students' negative attitudes towards research in relation to courses in, statistics and mathematics ${ }^{[3]}$. Attitude towards research is the significant indicator for academic performance and achievement and more positive one's attitude towards an academic subject, the higher the possibility for an individual to perform well academically. Attitude towards research among the medical and paramedical professionals is variable and research experience during graduate period is strongly associated with postgraduate research initiatives

\footnotetext{
${ }^{1}$ M.D, Assistant Professor, Department of Psychiatry, RVS medical college, Chittoor, India

${ }^{2}$ M.D., Prof \& Dean, Department of Forensic medicine, RVS medical college ,Chittoor, India

${ }^{3}$ Graduate, SVCP, Rvs Nagar, Chittoor, India

${ }^{4}$ M.Pharm, Ph.D, SVCP, Rvs Nagar, Chittoor, India

*Responding Author

(C) 2016 S Pasupula, L Obulesu, K Reddy; licensee IJIP. This is an Open Access Research distributed under the terms of the Creative Commons Attribution License (http://creativecommons.org/licenses/by/2.0), which permits unrestricted use, distribution, and reproduction in any Medium, provided the original work is properly cited.
} 


\section{Attitudes towards Research among Bachelor of Pharmacy and Doctor of Pharmacy Students: A Study from Tertiary Medical Institute}

${ }^{[4,5,6]}$ and future career achievements in academic activities .Limited data is available on research attitude among Pharmacy graduates and current study focuses on the study of attitude towards research among Bachelor of pharmacy and Doctor of Pharmacy internees.

\section{Aims and Objectives}

1. To assess the attitude towards research among Bachelor of pharmacy and Doctor of Pharmacy internees.

2. To compare the attitude towards research between Bachelor of pharmacy and Doctor of Pharmacy internees.

\section{METHODOLOGY}

This study was carried out at department of psychiatry, RVS medical college and hospital. Study sample includes the pharmaceutical students (B-Pharmacy and Pharm-D) studying at Sri venakteswara college of pharmacy. Attitudes towards the research was measured using Attitude towards research scale (ATR Scale). Statistical analysis was done by using EPI INFO and M.S. Excel software's.

\section{Attitude towards research questionnaire:}

It is a 30-item, self-rated, Likert scale which measures research attitude on the basis of five factors: The five factors included in the questionnaire were: usefulness of research in a career, research anxiety, positive attitudes toward the research, relevance of the research to life, and research difficulty. Attitudinal statements were scored on a 7-point Likert scale varying from 1.Strongly disagrees to 7 . Strongly agree. More the mean value of the response, more is the positive attitude and vice versa.

\section{Analysis and Results:}

\section{Socio demographic profile}

As shown in Table 1, total sample consists of hundred house surgeons which constitutes by fifty B-Pharm and Pharm D individuals respectively. Males constitute forty eight and a female constitutes fifty two in number. Mean age of participants is 23.5 years.

\section{Table 1:}

\begin{tabular}{|l|l|}
\hline Variable & Value \\
\hline Age : & \\
Mean Age of all the sample & 23.5 \\
\hline Sex : & \\
Male & 48 \\
Female & 52 \\
\hline
\end{tabular}

(c) The International Journal of Indian Psychology, ISSN 2348-5396 (e) | ISSN: 2349-3429 (p) | 171 


\section{Attitudes towards Research among Bachelor of Pharmacy and Doctor of Pharmacy Students: A Study from Tertiary Medical Institute}

Among total population, most of the individuals had variable and uncertain responses. People shared favourable responses (Mean value $=5.5$ to 7.0 ) towards eleven items $-2,4,12,15,19$, . Uncertain attitude (Mean value $=3.0$ to 5.5 ) was observed in seven items 1,3,5,6,7,8,9,10,11,13,14,16,17,18,20, ,22,23,24,25,26,27,28,29,30. Unfavourable response (1.0 3.0) is observed for the item 21.

\section{Table 2}

\begin{tabular}{|c|c|c|c|c|c|c|}
\hline Questionnaire & $\begin{array}{l}\text { Mean } \\
\text { value of } \\
\text { Pharm D } \\
\text { students } \\
\text { n=50 }\end{array}$ & 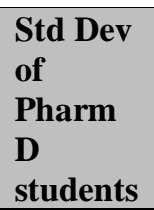 & $\begin{array}{l}\text { Mean } \\
\text { value of } \\
\text { B-Pharm } \\
\text { students } \\
n=50\end{array}$ & $\begin{array}{l}\text { SD of } \\
\text { Pharm } \\
\text { B- } \\
\text { Pharm }\end{array}$ & $\begin{array}{l}\text { Total } \\
\text { mean } \\
\text { value } \\
\mathbf{n}=50\end{array}$ & $\begin{array}{l}\text { Total } \\
\text { Std } \\
\text { Dev }\end{array}$ \\
\hline 1. Research makes me anxious. & 4.6667 & 1.0328 & 4.6585 & 1.6675 & 4.5833 & 1.661 \\
\hline 2 Research should be taught to all students. & 5.5 & 1.3784 & 5.7805 & 1.525 & 5.6667 & 1.5755 \\
\hline 3. I enjoy research. & 5.1667 & 1.472 & 5.3659 & 1.3371 & 5.2917 & 1.3677 \\
\hline 4. Research is interesting. & 5.6667 & 1.0328 & 5.6098 & 1.3762 & 5.5833 & 1.3342 \\
\hline 5. I like research. & 5.8333 & 0.9832 & 5.3171 & 1.5722 & 5.375 & 1.4964 \\
\hline 6. Research scares me. & 3 & 1.0954 & 3.122 & 1.9519 & 3.1667 & 1.8831 \\
\hline 7. Research is useful for my career. & 5 & 1.5492 & 4.9512 & 1.7168 & 5 & 1.6885 \\
\hline 8. I find it difficult to understand the concepts of research. & 5.1667 & 1.6021 & 3.7317 & 1.5973 & 3.9583 & 1.6626 \\
\hline 9. I make many mistakes in research. & 4 & 1.7889 & 4.0244 & 1.6806 & 4.0417 & 1.6626 \\
\hline 10. I love research. & 6 & 1.2649 & 5.0976 & 1.4284 & 5.1875 & 1.4241 \\
\hline 11. I am interested in research. & 5.1667 & 1.8348 & 5.3171 & 1.3498 & 5.25 & 1.4217 \\
\hline 12. Research is connected to my field of study. & 5.8333 & 0.9832 & 5.6585 & 1.4596 & 5.6042 & 1.4838 \\
\hline 13. Most students benefit from research. & 5.6667 & 1.0328 & 5.4146 & 1.5326 & 5.3542 & 1.5911 \\
\hline 14. Research is stressful. & 4.8333 & 2.2286 & 4.1951 & 1.8871 & 4.2292 & 1.9267 \\
\hline 15. Research is very valuable. & 6 & 1.2649 & 5.7561 & 1.3744 & 5.7292 & 1.3951 \\
\hline 16. Research makes me nervous. & 4.1667 & 1.9408 & 3.9268 & 1.4559 & 3.9583 & 1.4869 \\
\hline 17. I use research in my daily life. & 4.6667 & 2.2509 & 3.8537 & 1.7544 & 3.9792 & 1.8041 \\
\hline $\begin{array}{l}\text { 18. The skills I have acquired in research will be helpful } \\
\text { to me in the future }\end{array}$ & 4.8333 & 1.169 & 5.3415 & 1.4935 & 5.2917 & 1.4434 \\
\hline 19. Research is useful to every professional. & 5.5 & 1.2247 & 6.1707 & 1.2228 & 6.1042 & 1.2246 \\
\hline 20. Knowledge from research is as useful as writing. & 4.6667 & 1.633 & 5.0488 & 1.7882 & 5.0208 & 1.7442 \\
\hline 21. Research is irrelevant to my life. & 3.5 & 2.0736 & 2.6829 & 1.6192 & 2.8333 & 1.6927 \\
\hline $\begin{array}{l}\text { 22. Research should be indispensable in my professional } \\
\text { training }\end{array}$ & 4.8333 & 1.8348 & 4.2195 & 1.5734 & 4.2917 & 1.5839 \\
\hline 23. Research is complicated & 5.8333 & 0.9832 & 4.8537 & 1.7112 & 4.9375 & 1.6683 \\
\hline 24. Research thinking does not apply to my personal life. & 5 & 2.1909 & 3.4878 & 1.9381 & 3.6667 & 1.9929 \\
\hline 25. I will employ research approaches in my profession. & 5.5 & 1.0488 & 4.9512 & 1.7882 & 4.9792 & 1.7196 \\
\hline 26. Research is difficult. & 5.8333 & 1.472 & 4.5366 & 1.8721 & 4.6667 & 1.8604 \\
\hline $\begin{array}{l}\text { 27. I am inclined to study the details of research } \\
\text { procedures carefully. }\end{array}$ & 5.1667 & 0.7528 & 4.6585 & 1.1093 & 4.7083 & 1.0711 \\
\hline 28. Research is pleasant & 4.5 & 2.0736 & 3.9512 & 1.8296 & 4.0417 & 1.833 \\
\hline $\begin{array}{l}\text { 29. Research-orientated thinking plays an important role } \\
\text { in my daily life }\end{array}$ & 5.3333 & 1.0328 & 4.7805 & 1.8099 & 4.875 & 1.7213 \\
\hline 30. Research is a complex subject & 4.8333 & 1.169 & 5.1707 & 1.7015 & 5.1667 & 1.6417 \\
\hline
\end{tabular}




\section{Attitudes towards Research among Bachelor of Pharmacy and Doctor of Pharmacy Students: A Study from Tertiary Medical Institute}

\section{DISCUSSION AND CONCLUSION}

Attitude towards research is variable and proper education with training after assessing the attitude helps the individuals to change the individuals attitude more favourable and helps in better ongoing of research .The study revealed that there was a positive significant relationship between students' research self-efficacy and some of their personal and professional characteristics, including age and numbers of published papers. Earlier studies on research attitude found that several factors such as personal and professional characteristics, including age and numbers of published papers. ${ }^{[7,8]}$ In our study we found that among the total population, individuals have more uncertain responses than favourable or unfavourable responses. More number of uncertain responses can be explained by the experience of research as a tough and difficult course and want to avoiding research during the undergraduate training. It also indicates the need of education and research training during their undergraduate level.

Gender plays a key role on research attitudes and earlier studies shows that males experienced lower levels of anxiety compared to females. Graduating students whether male and female from the Faculties of Education, Arts and Social Sciences had negative attitude towards research ${ }^{[9]}$. In our study female individuals showed favorable responses than male individuals which differs from earlier studies.

The current study found that individuals from B-pharm and Pharm D have different responses and most of the Pharm D individuals are strongly agreeing that they love research and research is very valuable $(6.0+1.264)$ and they are strongly disagreeing for the question Research scares me $(3.0+1.9)$. B-pharm individuals are strongly agreeing that research is useful to every professional $(6.1707+1.2228)$ and at the same time they are disagreeing that Research is irrelevant to my life. $(2.6829+1.6192)$. Much varied responses and much variation is seen among the items I will employ research approaches in my profession, Research is difficult, I am inclined to study the details of research procedures carefully, Research is pleasant, Researchorientated thinking plays an important role in my daily life. The variation among two groups can be explained by the fact of early exposure of research to the individuals of Pharm D than Bpharm individuals and moreover inclusion of Research and methodology subject in the educational curriculum of Pharm D course. ${ }^{[10]}$

As the sample recruited for the study is from single institution results cannot be generalised to the whole population is one of the limitation in our study. Future research is needed with large sample size at clinical and community level. The results are concluding that attitude towards research among Pharmacy internees is variable and Pharm D individuals are having more favourable responses than B-Pharm internees. This results shows the need of research oriented programmes to improve the awareness and knowledge regarding the research. Proper awareness 


\section{Attitudes towards Research among Bachelor of Pharmacy and Doctor of Pharmacy Students: A Study from Tertiary Medical Institute}

towards research to personals at undergraduate level and inclusion of research in undergraduate curriculum is required for more favourable attitude which helps in better professional outcomes.

\section{Acknowledgments}

The author appreciates all those who participated in the study and helped to facilitate the research process.

\section{Conflict of Interests}

The author declared no conflict of interests.

\section{REFERENCES}

1. Faustino e. oguan jr et al., Attitude and anxiety towards research, its influence on the students' achievement in the course. Asian journal of management sciences \& education vol. 3(4) October 2014.

2. Papanastasiou, e. c. (2005). Factor structure of the attitudes towards research scale. statistics education research journal, 4(1), 16-26. www.stat.auckland.ac.nz/serj

3. Adams, n. a., \& Holcomb, w. r. (1986). Analysis of the relationship between anxiety about mathematics and performance. psychological reports, 59, 943-948.

4. Houlden, R.L 2004. Medical students' perceptions of an undergraduate research elective. med. teach. 26 (7), 659-661.

5. Solomon, s.s., tom, s.c., Pichert, j., Wasserman, d., powers, a.c.,2003. Impact of medical student research in the development of physician-scientists. j. invest. med. 51 (3), 149-156.

6. Brancati, f.l., mead, l.a., levine, d.m., martin, d., margolis, s., klag, m.j., 1992. Early predictors of career achievement in academic medicine. jama 267 (10), 1372-1376.

7. Dr. naser zamani-miandashti et al., The relationship between research self-efficacy, research anxiety and attitude toward research: a study of agricultural graduate students ., journal of educational and instructional studies in the world November 2013, volume: 3 issue: 4 article: 09 issn: 2146-7463 .

8. Sadia shaukat et al ., Postgraduate students' attitudes towards research .,bulletin of education and research june 2014, vol. 36, no. 1 pp. 111-122) .

9. Bandele s.o. et al., Patterns of university graduating students' attitude to research work et al ., international journal of educational research and technology ., ijert: volume 4 [3] September 2013: 98-103.

10. Educational curriculum of B-Pharm and Pharm D individuals.

How to cite this article: S Pasupula, L Obulesu, K Reddy (2016), Attitudes towards Research among Bachelor of Pharmacy and Doctor of Pharmacy Students: A Study from Tertiary Medical Institute, International Journal of Indian Psychology, Volume 3, Issue 4, No. 77, ISSN:23485396 (e), ISSN:2349-3429 (p), DIP:18.01.077/20160304, ISBN: 978-1-365-51571-2 